\title{
The Fundamental Determinants of Credit Default Risk for European Large Complex Financial Institutions
}

Inci Ötker-Robe and Jiri Podpiera 


\title{
IMF Working Paper
}

Monetary and Capital Markets Department

\section{The Fundamental Determinants of Credit Default Risk for European Large Complex Financial Institutions}

\section{Prepared by İnci Ötker-Robe and Jiri Podpiera*}

\author{
Authorized for distribution by İnci Ötker-Robe
}

June 2010

\begin{abstract}
This Working Paper should not be reported as representing the views of the IMF. The views expressed in this Working Paper are those of the author(s) and do not necessarily represent those of the IMF or IMF policy. Working Papers describe research in progress by the author(s) and are published to elicit comments and to further debate.
\end{abstract}

This paper attempts to identify the fundamental variables that drive the credit default swaps during the initial phase of distress in selected European Large Complex Financial Institutions (LCFIs). It uses yearly data over 2004-08 for 29 European LCFIs. The results from a dynamic panel data estimator show that LCFIs' business models, earnings potential, and economic uncertainty (represented by market expectations about the future risks of a particular LCFI and market views on prospects for economic growth) are among the most significant determinants of credit risk. The findings of the paper are broadly consistent with those of the literature on bank failure, where the determinants of the latter include the entire CAMELS structure - that is, Capital Adequacy, Asset Quality, Management Quality, Earnings Potential, Liquidity, and Sensitivity to Market Risk. By establishing a link between the financial and market fundamentals of LCFIs and their CDS spreads, the paper offers a potential tool for fundamentals-based vulnerability and early warning system for LCFIs.

JEL Classification Numbers: G21, G28, C12

Keywords: Large Complex Financial Institutions, dynamic panel data, Credit Default Swap, CAMELS, vulnerability analysis, early warning systems.

Author's E-Mail Address:iotker@imf.org, jpodpiera@imf.org

The authors would like to thank Turgut Kisinbay, Christian Schmieder, and participants at the IMF seminar for helpful comments and suggestions. 


\section{Contents}

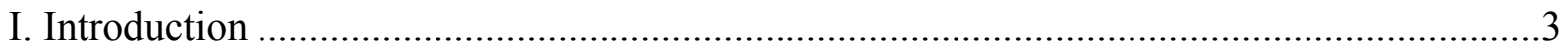

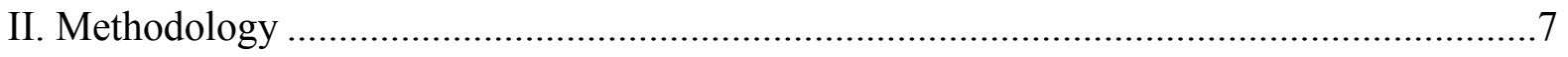

III. Definition of the Dependent and Explanatory Variables ..............................................

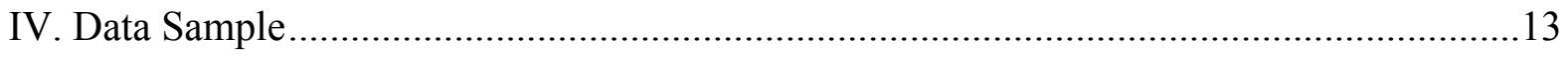

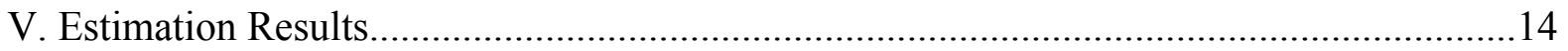

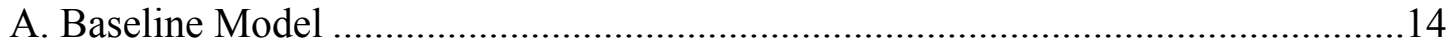

B. Robustness to Alternative CAMEL Indicators............................................... 18

C. Robustness to Alternative Market Risk Indicators................................................21

VI. Concluding Remarks and Policy Implications ..........................................................24

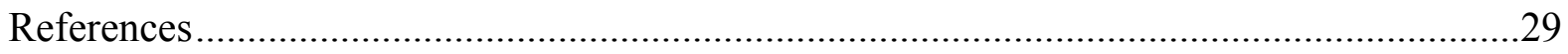

Tables

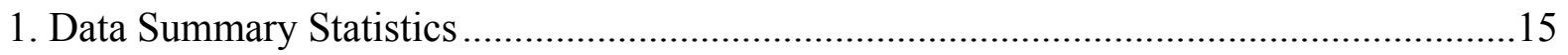

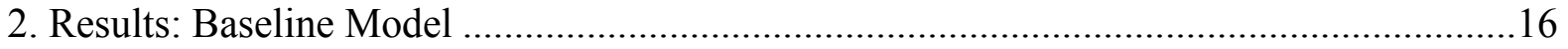

3. Results: Two-step Estimates of the Baseline with Alternative CAMEL Indicators ............20

4. Results: Two-step Estimates of the Baseline with Alternative Market Risk Indicators ......23

Figures

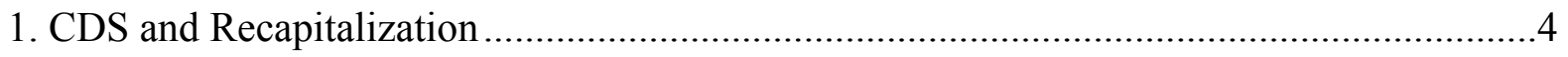

Appendixes

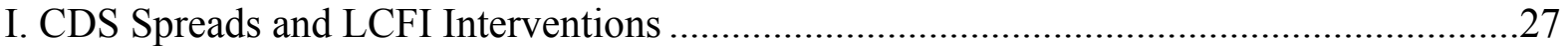

II. Fundamental Risk from LCFI's Risk-Return Profile ...................................................28 


\section{INTRODUCTION}

1. The financial crises experienced in recent decades prompted efforts to develop models that could help identify the possible factors underlying the crises. The ongoing global financial crisis has intensified these efforts, with policymakers starting to focus attention on developing indicators and methods that could assist in a timely identification of highly vulnerable countries. In this context, efforts focused on developing early warning systems (EWSs) that could give policymakers and market participants some warning that a crisis is likely to occur.

2. Such EWS models could provide a useful tool for surveillance. They could help policymakers to detect underlying economic weaknesses and vulnerabilities, thereby providing early warnings about possible future systemic crises. They could also trigger prompt interventions to take preemptive steps toward reducing the risk of experiencing a crisis. With the possibility that the nature of future crises may differ from the past ones, the EWS models need to be forward-looking, and used along with other quantitative and qualitative tools and analyses to help avoid false alarms.

\section{The ongoing financial crisis has underscore the crucial role that large complex} financial institutions (LCFIs) have played in triggering and propagating the pressures, hence highlighting the need to develop an EWS for LCFIs. While such LCFIs have been excluded from EWS studies ${ }^{1}$ in the past, on the basis of their close supervision and more complex structure, a number of LCFIs (mainly in Europe and the United States) have been at the center stage of the ongoing financial crisis, prompting the IMF and policymakers to start devoting significant resources to better understand their activities, business and funding models, risks and exposures, and potential spillover effects they can generate in and outside of the countries they are headquartered.

4. This paper attempts to identify the factors that affect credit default risk of a number of European LCFIs, as a way to provide a fundamentals-based surveillance tool for systemic banks and that can potentially serve as an early warning device. For a group of European financial institutions characterized by the large size of their assets, complexity and interconnectedness of their operations, and significant cross border presence, the paper develops a methodology to estimate the determinants of credit default risk as a function of a set of market, financial, and macroeconomic fundamentals affecting the LCFIs.

\footnotetext{
${ }^{1}$ Barr and Siems (1994) exclude banks that exceed \$300 million in total assets and Wheelock and Wilson (2000) exclude banks that operate foreign branches.
} 


\section{Toward that objective, the paper considers credit default risk as a useful statistic} for financial surveillance and in an EWS for LCFIs. Heightened financial distress gets reflected in an increased default risk, which could be a pre-step to an eventual default or failure. Identifying the determinants of credit risk provides information on the determinants of creditrisk-implied probability of default. A standard structural credit risk model combined with key financial soundness indicators is used to determine the fundamentals driving credit default risk of selected European LCFIs. ${ }^{2}$

\section{The credit default risk is measured by the Credit Default Swap (CDS) spread in}

this paper. In a CDS contract, the buyer of a protection against default is entitled for compensation in the event of the issuer's default on the underlying asset. The seller of the protection receives periodic payments until the default event occurs or the contract matures. The spread is the price of the credit default risk of the underlying asset. Figure 1 provides some support for the choice of CDS spreads as an appropriate indicator of distress. It shows a strong link between the CDS spread prior to an official intervention and the extent of needed recapitalization (a form of intervention), with the CDS spread appearing to correlate positively with the size of the losses. ${ }^{3}$

Figure 1. CDS Spreads (Vertical Axis, p.p.) and Recapitalization (Percent of total assets) $1 /$

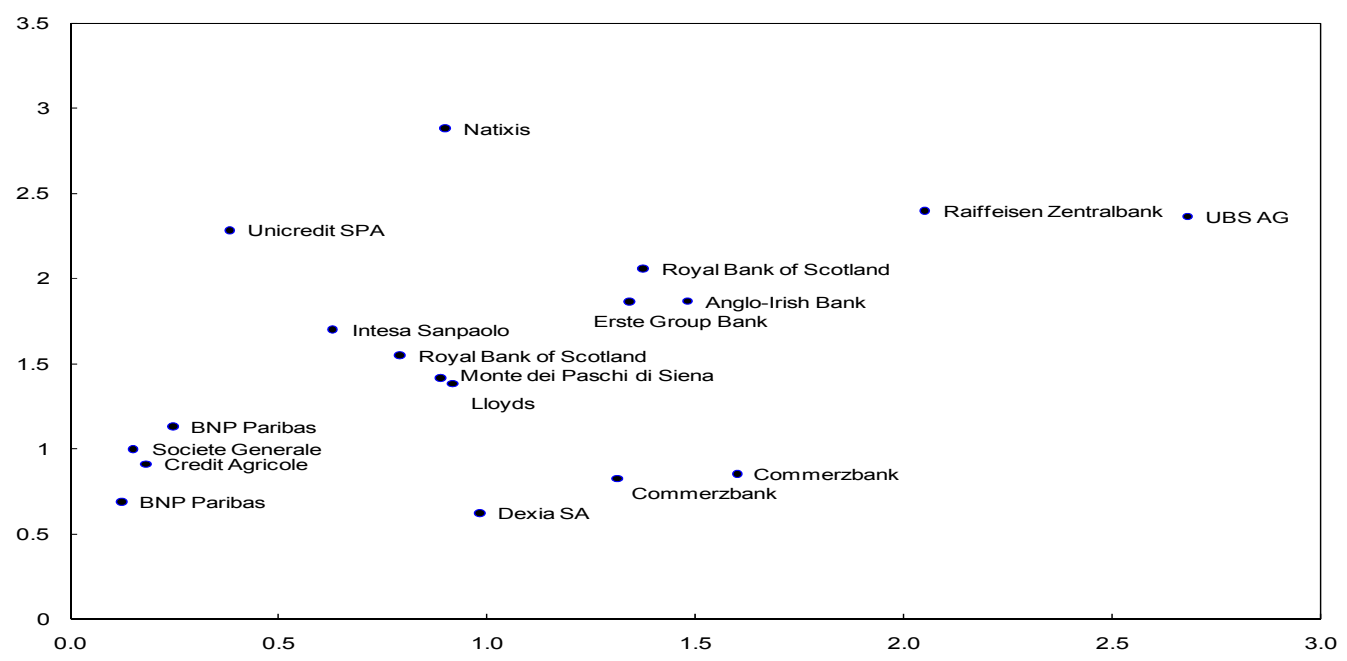

1/ The actual needed recapitalization of LCFIs in the sample during August 2008 through May 2009, measured as capital (and in one case asset purchase) over bank's total assets (i.e., the capital needed to cover losses in total assets). The credit default swap (CDS) 5 Y spread is measured as a 30-day average before the government intervention took place.

\footnotetext{
${ }^{2}$ This work relates to a parallel paper on EWS for LCFIs that uses a profit model to estimate the determinants of the probability of LCFI distress.

${ }^{3}$ The regression yields Recapitalization $=0.62\left(\right.$ s.e. 0.09) $C D S ; R^{2}$ (adj.) $=0.73$. See also Appendix I, Table 5 .
} 
7. There are several well-recognized advantages of using CDS spreads rather than bond credit spreads for assessing credit risk:

- $\quad$ The CDS spread is a more direct measure of credit risk than corporate bonds credit spreads. The credit spread from corporate bonds is derived by subtracting a riskfree interest rate from the corporate bond yield. However, the choice of the reference risk-free asset and the method to derive zero-coupon yield curve affects the level of the spread. In contrast, the CDS is already a spread, since it is priced such that no arbitrage exists between investing in a riskless bond and buying a defaultable bond, and protecting against default by purchasing the CDS.

- The CDS spread does not seem to contain liquidity components as corporate bond credit spreads. Driessen (2005) shows that more than half of the variation in corporate bond credit spreads relates to time-varying compensation for liquidity and to some extent the tax treatment of corporate bonds (while corporate bonds are subject to state tax, government bonds are not). In contrast to credit bond spreads, the CDS spread is not distorted by tax issues and according to Fabozzi et al. (2007) does not contain any liquidity premium.

- $\quad$ The CDS spread leads in the credit risk price-discovery process over corporate bond credit spreads. According to Blanco et al. (2005), the no default components in corporate bond credit spreads make responsiveness of the credit spreads to changes in credit quality slower and weaker than that of the CDS spread. The authors also show that the CDS spread represents the upper bound of credit risk, while credit spreads the lower bound.

8. The specification of the CDS spread model is based on the theory developed for the corporate bond credit spread by Merton (1974). Benkert (2004) derived the applicability of this theory to the CDS market. Merton's pricing theory of corporate bond spreads - known as the structural approach - implies that the price of corporate debt is a function of the debt-to-firm value, a variance of the firm's value, and a risk-free term premium. Recent literature (CollinDufresne et al., 2001; Blanco et al., 2005; and Ericsson et al., 2009) extends the framework by some additional factors such as stock market returns and the slope of the yield curve as a response to the so called credit spread puzzle - the outcome that structural variables explain only a moderate portion of credit spread variability (see Duffee, 1998, and Collin-Dufresne et al., 2001).

\section{Although the credit spread puzzle seems to dominate corporate bond credit} spreads, some other variables might help explain the pricing of banks' CDS spreads. Ericsson et al. (2009) find that the puzzle pertains to the corporate bond spreads, due to liquidity and tax effects, and find higher explained variability by structural variables for CDS spreads than for the corporate bond credit spreads. Nevertheless, there are other factors that are usually 
considered in banks' credit risk (Rating agencies) or early warning systems (Banks' supervisory authority):

- Credit rating agency risk assessments play an important role in market pricing. The assessment is usually formed during the rating process in which the rating agency analyzes a bank's financial indicators, business strategy, and organization, and undertakes multiple discussions with the bank management. A number of recent studies (see, e.g., Avramov et al., 2009, and Li et al., 2005) establish an empirical link between credit rating and stock returns. In studies by Aunon-Nerin et al. (2002) and Abid and Naifar (2006), credit ratings explain large portion of CDS spread variability.

- $\quad$ Financial indicators represent important information about banks' credit default risk also in the early warning systems used by bank supervisory authorities. The components of CAMELS - an acronym for Capital Adequacy, Asset Quality, Management Quality, Earnings Potential, Liquidity, and Sensitivity to Market Riskhave traditionally been the yard stick for an assessment of banks' performance. Since CAMELS combines the financial soundness (credit risk) and market (market risk) indicators, it is used by banking sector supervisory authorities (King et al., 2006) and rating agencies (Rawcliffe et al., 2008) to assess soundness of banks. ${ }^{4}$

10. The paper estimates the CDS spread model specified with the above indicators by a Dynamic Panel Data two-step Estimator. The findings suggest that the variation in CDS spreads is explained by differences across LCFIs. For a sample of 29 European LCFIs over 2006-2008, the data variation stems more from the variation across LCFIs than from the time dimension; the average CDS spread increased by a factor of 11 , while the variability (standard deviation) increased 18 times between 2006 and 2008. Moreover, in the model's dynamic specification, the variation in the time dimension is to some extent ( 37 percent) explained by the lagged dependent variable. The remaining explained variability is due to the bank specific and market fundamentals of the LCFIs (52 percent).

\section{Among the bank-specific and market fundamentals are variables related to actual} business models and uncertainty. Among the bank specific fundamentals, the most important factors are the Efficiency Ratio, the Share of Trading Income, Net Interest Income Ratio, return on assets (ROA), and the share of Short-term Borrowing in Total Liabilities. These variables represent the Management, Earnings potential, and Liquidity elements in the CAMEL structure. The significant market fundamentals relate to market (equity Capital) and economic (Asset quality) uncertainty, represented by Implied Volatility from Options, the KMV EDF5, the Slope of the Yield Curve, and the Volatility of GDP growth to which banks are effectively exposed.

\footnotetext{
${ }^{4}$ Appendix II provides some formal motivation for the choice of variables in the baseline model.
} 
12. The remaining sections of the paper are organized as follows. Section II describes the methodology. The definition of the LCFI's and the sample of banks are given in Section III. Section IV defines the variables and describes their expected relationship with CDS spreads. Section $\mathrm{V}$ presents the results for the baseline regression and robustness analysis to alternative CAMEL and Market Risk indicators. Section VI concludes.

\section{Methodology}

13. The following model specification of credit default swaps (CDS) spread dynamics accounts for potential persistence in CDS spread and for bank-specific credit risks. The dynamic specification is motivated by findings of unit root and heteroscedasticity in credit spreads by Pedrosa and Roll (1998) and Bierens et al. (2003). In addition, Blanco et al. (2005) used a specification with a lagged dependent variable. Formally:

$$
C D S_{i, t}=\rho C D S_{i, t-1}+X_{i, t}^{\prime} \beta+Z_{t}^{\prime} \gamma+u_{i, t}
$$

where, $C D S_{i}$ represents the CDS spread value for bank $i$ at time $t$; $C D S_{i, t-1}$ denotes the oneperiod lagged value of CDS spread for bank $i$ and $\rho$ measures the degree of persistence. Further, $X_{i, t}$ stands for a vector of explanatory variables observed for bank $i$ in period $t$ and $\beta$ contains corresponding sensitivities to particular explanatory variables. Banks' credit risk factors, summarized in $Z_{t}$, represent banks' common determinants of CDS spread (at the sample and country level) and $\gamma$ contains the associated parameters. The composite error term $u_{i, t}$ is composed of a white noise component $\varepsilon_{i, t}$ and a bank-specific credit risk factor $v_{i}$.

\section{The model parameters are estimated using Arellano-Bond GMM method (Arellano} and Bond, 1991). There are several reasons for this choice. First, some explanatory variables such as ratings or variance of equity are endogenous (predetermined) to the CDS spread and need to be instrumented accordingly. Second, the bank-specific time invariant credit risk factors might be correlated with other explanatory variables which are accounted for by first differencing. Third, the presence of lagged dependent variable introduces autocorrelation in residuals and hence it is instrumented with its lagged value. Fourth, financial market variables often exhibit a random walk process and thus ought to be instrumented by differenced lagged values (hence Arellano-Bond method). Finally, the Arellano-Bond method is designed for samples with $\mathrm{T} / \mathrm{N} \rightarrow 0$. It is therefore the appropriate estimator since the panel data set has a short time dimension $(\mathrm{T}=3)$ relative to the number of banks $(\mathrm{N}=29)$.

\section{The Arellano-Bond GMM dynamic panel data estimator is applied to first- difference of the equation (1), which removes the fixed effects:}

$$
\Delta C D S_{i, t}=\rho \Delta C D S_{i, t-1}+\Delta X_{i, t}^{\prime} \beta+\Delta Z_{t}^{\prime} \gamma+\Delta \varepsilon_{i, t}
$$

The actual estimation of equation (2) proceeds with one-step and two-step estimators. In the one-step estimation the $\varepsilon_{i, t}$ are assumed to be i.i.d., hence the (T-2) square matrix $H$ in the 
weighting matrix $\left.W_{l}=N^{l} \sum_{i} M_{i}{ }^{\prime} H M_{i}\right)^{-1}$ has two's on the main diagonal and minus one's on the first off-diagonals. Matrix $W$ is used to produce consistent one-step parameter estimates:

$$
\delta_{1}=\left(D^{\prime} M W_{1} M^{\prime} D\right)^{-1} D^{\prime} M W_{1} D^{\prime} \triangle C D S,
$$

where $\delta_{1}=\left[\hat{\rho}, \beta^{\wedge}, \gamma^{\wedge}\right], D=\left[\Delta C D S_{i, t-1}, \Delta X_{i, t}, \Delta Z_{t}\right]^{\prime}$ and $M$ is a matrix of instruments containing the $T(T-1) / 2$ sequential instruments for the endogenous explanatory variables (lagged levels of endogenous variables) and in addition the differenced exogenous variables and other instruments. The one-step parameter estimates are used to derive an optimal weighting matrix $\left.W_{2}=N^{l} \sum_{i} M_{i}{ }^{\prime} \Delta \varepsilon_{i 1} \Delta \varepsilon_{i 1}{ }^{\prime} M_{i}\right)^{-1}$, where $\Delta \varepsilon_{i l}=\Delta C D S_{i}-D_{i}{ }^{\prime} \delta_{1}$. The equation (3) run with $W_{2}$ instead of $W_{l}$ produces the two-step parameter estimates.

\section{As long as the estimates in the two steps differ, two-step estimates are preferable} since they use an optimal weighting matrix (the covariance matrix is robust to panel specific autocorrelation and heteroscedasticity). The parameters in both steps are asymptotically equivalent if the errors are i.i.d. (see Arellano and Bond, 1991). Nevertheless, the two-step standard errors are found to be downward biased in small samples (see for instance Windmeijer, 2005), whereas the asymptotic standard errors in the one-step estimator tend to be unbiased. Since the sample in this paper is relatively small, the statistical inference in the twostep estimator is based on feasible estimator of the finite sample correction for the linear efficient two-step estimator, derived by Windmeijer (2005).

\section{DEFINITION OF THE DEPENDENT AND EXPLANATORY VARIABLES}

17. The dependent variable in the model, which aims at approximating credit default risk for each LCFI, is provided by the latter's CDS spread. Banks' credit default swaps daily last price quotes represent swaps on senior debt with a maturity of five years (most liquid maturity) and are downloaded from Bloomberg. The dependent variable is the yearly average of daily data.

\section{Capital adequacy is measured by four alternative variables: Tier I and Tier II} ratios, Leverage ratio, and $\mathrm{Z}$-score.

- $\quad$ Tier I capital represents the ratio of capital (shareholders capital, reserves, and hybrid capital to certain limits) divided by risk-weighted assets and is taken as reported by each bank. Tier II capital is a ratio of secondary capital (undisclosed reserves, revaluation reserves, general provisions, hybrid instruments and subordinated term debt) to risk weighted assets. Tier II is computed as the residual from total capital adequacy ratio and Tier I capital ratio obtained from Bloomberg. Both capital ratios represent capital buffers for loss absorption and thus they should correlate negatively with the credit risk. 
- $\quad$ Leverage measures the size of Average Total Assets relative to Average Total Common Equity. It is one of the standard indicators implied by the structural approach to the pricing of default risk. Higher leverage (lower capitalization) would correlate positively with default risk.

- $\quad$ Z-score is a derivative measure of bank capitalization and gauges available funds for loss absorption. Following Boyd and Runkle (1993) it is computed as a sum of ROA and Equity to Total Assets ratio scaled by the standard deviation of ROA. A higher value of Z-score indicates a higher resistance to shocks and implies a lower credit risk.

19. The quality of banks' assets is measured by three ratios: Loan-loss Provisions to Total Loans, Non-performing Loans to Total Loans, and the Loan-loss Reserves to Nonperforming Loans. While the Loan-loss Provisions ratio measures the credit risk from a bank's portfolio generated within one year, the Share of Non-performing Loans represents the stock of non-performing loans in the loan book. Both indicators should correlate positively with the credit risk, since higher newly expected losses and a higher stock of non-performing loans increase bank's vulnerability and default risk. Loan-loss Reserves serve to cover nonperforming loans and thus their ratio to non-performing loans should, other things being equal, correlate negatively with the CDS spread.

\section{The quality of management is assessed based on Management Flexibility, Long-} term Issuer Default Rating, and differences in the business models.

- $\quad$ Management quality (approximated by cost efficiency scores) has been associated with bank failures in a number of recent studies, e.g., Barr and Siems (1994), Wheelock and Wilson (2000), and Kick and Koetter (2007). Cost efficiency is approximated by a simple ratio of Operating Expenses to Total Revenues, denoted as Efficiency Ratio, which measures management flexibility to adjust costs to changes in the business development signaled by revenues. The higher is the Efficiency Ratio, the higher is the default risk.

- $\quad$ Long-term Issuer Default Rating contains judgment on all the risks stemming from bank's business. Produced by Fitch Ratings, ${ }^{5}$ this composite rating takes into consideration a number of external and internal qualitative and quantitative factorsrisks pertaining to credit, market, operational, funding, liquidity, bank's structure, business diversification, management and strategy, and capitalization. On the numerical scale, a higher rating value means a higher credit default risk.

\footnotetext{
${ }^{5}$ The rating is not available for DnB NOR ASA. No change in rating was assumed in estimation.
} 
- $\quad$ Trading income as a percentage of total revenues accounts for the differences in banks' business model. Investment banking oriented banks would report a high portion of revenues from trading income, while banks with dominantly commercial bank business would have a lower share. Since the trading income is more volatile than interest income, hence more risky, banks with a higher ratio may be expected to pay a relatively higher default risk premium.

21. Earnings potential is represented by three profitability measures: Net Interest Income ratio, Return on Equity (ROE), and Return on Assets (ROA). The Net Interest Income ratio is calculated as the percentage interest yield of interest bearing assets; ROE (ROA) is computed as Net Income divided by Total Common Equity (Total Assets).

- $\quad$ The Net Interest Income ratio is a rough measure for the lending margin charged by a particular bank - a risk taking measure. Since loans are priced according to their risk score, a higher lending margin may signal higher risk-taking. Therefore, assuming negligible differences in funding costs across LCFIs, a higher Net Interest Income ratio would imply higher default risk.

- $\quad$ The $R O E(R O A)$ measures the profit a bank can generate given shareholders' capital (total assets), hence should correlate negatively with default risk. A higher ROE or ROA indicates better profit prospects for growth and resilience to shocks, and thus should be associated with lower credit risk.

22. A bank's liquidity/funding position is measured by four ratios: Loan to Deposit ratio, Share of Wholesale Funds to Total Liabilities, Short-term Borrowing to Total Liabilities, and Liquid Assets to Total Assets.

- $\quad$ The higher the Loan to Deposit ratio, the higher the dependence on nondeposit funding. Since deposits are viewed to be more stable and usually cheaper sources of funding, greater dependence on wholesale funding may signal higher funding risk and higher riskiness for a bank. The Share of Wholesale Funds to Total Liabilities is an alternative measure of bank's reliance on wholesale funding.

- $\quad$ Short-term Borrowing to Total Liabilities and Liquid Assets to Total Assets measure the degree to which banks can withstand a sudden liquidity distress. A bank with a higher share of short-term borrowing would be more vulnerable in the event of a bank run (hence a higher CDS spread). A bank with a higher share of liquid assets would prove more resilient to liquidity pressures.

23. Market risk is represented by both bank-specific and common market factors. The historical Variance of a bank's Equity Price, Volatility Implied by the Options Prices, Cost of Funds, Expected Default Frequency (EDF), and effective GDP growth and GDP volatility 
affecting a bank are measured at the bank level, while the Slope of the Yield Curve along with the actual and expected GDP growth and GDP volatility are collected at the country level. Bloomberg Euro 500 stocks index is also used as a common market factor.

- $\quad$ Both the Variance of Equity Price and the Options Implied Volatility (bank specific factors) contain distinct information about the CDS spread. The Variance of Equity Price approximates the variance of a firm's value in the structural pricing theory of credit derivatives. Firm-specific equity volatility is found to be an important determinant of bond credit spreads (Campbell and Taksler, 2003). It is computed as the historical variance of bank's equity price in a particular year. In addition, Cremers et al. (2004) argue that besides the historical equity price volatility, the Options Implied Volatility contains additional information for pricing credit risk. The implied volatility is extracted from the equity options with one year maturity using Bloomberg. Since volatility essentially measures the uncertainty of return to investment in the bank's equity, it should positively correlate with credit default risk.

- $\quad$ Moody's KMV EDF (a bank specific factor) is a widely used market-based statistics for credit default risks. The underlying information in the EDF ( 5 years) is the market value and volatility of equity and the book value of liabilities. A tight relation between Equity and CDS spread is expected since these two markets are linked through capital structure arbitrage. A higher EDF in general implies a higher CDS spread.

- Cost of Funds (a bank specific factor) is approximated by the ratio of Interest Expense to Total Liabilities and signals banks' liquidity and risk-taking characteristics. An increasing cost of funds means that a bank is willing to pay extra premium on funds. It does so usually in connection with problems in managing liquidity. Persistently higher cost of funds relative to its peers, other things being equal, suggests that a bank takes higher risk in its loan book to pay higher cost of funds. Therefore, Cost of Funds would correlate positively with bank's default risk.

- $\quad$ The Slope of the Yield Curve (a common market factor) reflects growth prospects of the economy and expected future short-term interest rates. A steepening of the yield curve signals positive prospects for economic growth (declining non-performing loans and improving recovery rate) and thus higher future short-term interest rates. A steepening of the yield curve (future improvement in economic conditions) should hence correlate negatively with credit default risk.

- $\quad$ The Slope of the Yield Curve was derived here from the return on 10-year government bonds and the overnight interbank market rate. While the choice of the long-term rate is straightforward, the choice of risk free short-term rate is not. A usual choice in the literature is the 3-month money market rate or the treasury bills rate. However, during the crisis years (2007 and 2008) the 3-month rate was plagued by credit and liquidity 
risks. ${ }^{6}$ In order to filter out the credit and liquidity risks, the 3-month overnight interest rate swaps (O/N IRS) would be the best choice, since only the interest is traded (no risk of collateral), though an O/N IRS is not available for all countries in the sample.

Nevertheless, since there is very little difference between the overnight rate and 3-month $\mathrm{O} / \mathrm{N}$ IRS, the risk free short-term interest rate was approximated by the overnight rate. Banks were assigned the Slope of the Yield Curve according to the country where a particular LCFI is incorporated.

- The economic climate facing an LCFI is measured by two indicators: (i) the GDP of the country where an LCFI is incorporated and (ii) the LCFI-specific GDP growth and its volatility (hence a common market and bank-specific factor, respectively). The first is given by the GDP growth and its volatility ${ }^{7}$ based on the LCFI's country of incorporation. For the second, we compute a weighted average of GDP growth of countries to which the LCFI has exposure, and its volatility, for each LCFI, where the weights are derived from the share in the LCFI's revenue of countries to which the LCFI has exposure. ${ }^{8}$ GDP growth is negatively correlated with the share of non-performing loans and positively with the recovery rate. On the other hand, the volatility of GDP means uncertainty in earnings. Therefore, a higher GDP growth (volatility) is expected to correlate negatively (positively) with default risk.

- $\quad$ The economic outlook (as both a common market factor and a bank-specific factor) was approximated by the one-year ahead expected GDP growth of the country in which a particular LCFI is incorporated, as well as the effective expected GDP growth of countries to which the LCFI has exposure (weights given by the shares in a given LCFI's revenue). Forecast for the upcoming year was extracted from the December surveys by Consensus Forecasts (CFs); the use of CFs comes naturally as the respondents to the CF surveys are generally LCFIs and thus the expectations are their own.

- $\quad$ Finally, the overall current economic climate measured by the stock market index and stock market volatility (common market factors) might play a role for the CDS market as well. Due to known time lags between economic slowdown (acceleration) and credit

\footnotetext{
${ }^{6}$ In well functioning markets, the spread between 3-month and overnight rate is constant and minimal (up to 10 basis points). During the crisis, the spread increased significantly (to 70 basis points) as the 3 -month market had become illiquid.

${ }^{7}$ Following Tang and Yan (2010), the GDP volatility is estimated using the unexpected GDP growth rate. In particular, the following $A R(1)$ process is estimated using quarterly GDP growth rates $(g d p)$ for each country $i$ : $\Delta g d p_{i, t}=\alpha_{i}+\rho_{i} \Delta g d p_{i, t-1}+\varepsilon_{i, t}$. The GDP volatility in time $\mathrm{t}$ is equal to $(\pi / 2)^{0.5}\left|\varepsilon_{t}\right|$. Yearly data is obtained by averaging quarterly observations.

${ }^{8}$ Tang and Yan (2010) find that bank-level determinants are more informative than common macroeconomic variables.
} 
portfolio deterioration (improvements), the performance of the stock market leads the expectations about shocks to banks from economic climate and affects their price of default risk. The stock market index (Bloomberg Euro 500 stocks index) and the European stock market volatility (VSTOXX) would correlate with the credit default premium negatively and positively, respectively.

\section{Data SAMPle}

24. There is no commonly agreed definition of a Large Complex Financial Institution (LCFI), given the difficulties in defining systemic importance (Huertas, 2009). Size is an important but generally not sufficient condition for systemic importance (Marsh, 2003). In general, there is broad agreements that banks that are large (significant in size and activities) and complex (interconnected with other institutions and markets, or have significant cross country exposures) can pose significant systemic risk. Recent work for the G-20 Group (see IMF, 2009) set three key criteria for systemically important institutions and markets along these lines: size, interconnectedness, and substitutability. The first three categories of Thomson (2009) classification of systemically important financial institutions refer to size, contagion, and correlation.

\section{The LCFIs included in the sample are chosen from the set of systemically}

important banks in Europe. They are either large in their domestic markets (local market interconnections represent a high local systemic risk, with their assets as a percent of domestic claims exceeding 10 percent), and/or they have large cross border exposures (the share of foreign revenues in the bank's total revenues exceeds 30 percent). These criteria and data availability limitations lead to a sample of 29 LCFIs in 12 European countries, spanning a period of five years during 2004-2008 - a balanced panel data structure.

26. The following banks are included in the sample: Erste Group Bank and Raiffeisen International (Austria); Dexia SA and KBC Groep (Belgium); HSBC Plc, Barclays Plc, Royal Bank of Scotland, Lloyds, and Standard Charter (UK); Danske Bank (Denmark); BNP Paribas, Societe Generale, Credit Agricole, and Natixis (France); Deutsche Bank AG and Commerzbank (Germany); Bank of Ireland, Anglo-Irish Bank, and Allied-Irish Bank (Ireland); Unicredit SPA, Intesa Sanpaolo, and Banca Monte dei Paschi di Siena (Italy); DnB NOR ASA (Norway); Banco Santander and BBVA (Spain); Nordea Bank AB and Svenska Handelsbanken (Sweden); UBS AG and Credit Suisse (Switzerland).

27. Data is sourced from multiple databases. Banks' financial indicators, market prices, and macroeconomic variables are obtained from Bloomberg, Economic Intelligence Unit, Consensus Forecasts, Datastream, Stoxx.com, and Credit Edge. The data coverage of banks' financial statements and ratios by Bloomberg for 2004-2008 is about 70 percent of the needed 
yearly data. The missing data has been filled directly from bank's publically available statements, after a thorough data correspondence check.

28. The descriptive statistics suggest that market indicators detect problems better, compared with financial soundness indicators. Table 1 below contains the yearly average summary statistics of the sample. To illustrate, while the CDS spread tripled in 2007, the financial soundness indicators did not show signs of a crisis until 2008. In contrast, the set of market related indicators were indicative of an upcoming crisis (in particular, rising implied volatility and the flattening slope of the yield curve).

29. Importantly, banks show diverse credit risk developments amid the crisis. While the average CDS spread increased 11 times during the current crisis (from 9.6 in 2006 to 108 in 2008), the standard deviation of CDS spread across LCFI's increased by a multiple of 18 (Table 1). Therefore, the structure of data variability is biased toward cross-sectional differences in banks characteristics.

\section{ESTIMATION RESULtS}

\section{A. Baseline Model}

30. As discussed in Appendix II, the design of the baseline unrestricted dynamic model is based on a structural approach that contains most common financial soundness indicators. At the core of the model are the structural variables, that is, the leverage ratio and market risk indicators (Options Implied Volatility, Slope of the Yield Curve, and the Bloomberg 500 Stocks Index). Additional variables comprise usual indicators of asset quality (Loan-loss Provisions Ratio and the Share of Non-performing Loans), management quality (Efficiency Ratio and Trading Income Ratio), earnings potential (Net Interest Income Ratio and ROA), and liquidity (Loans to Deposits Ratio).

Two types of estimates are provided for statistical inference: using the One- and the Twostep estimator, respectively. While the One-step estimator assumes i.i.d. errors, the Two-step estimator takes into account the actual structure of the residuals. Therefore, as long as there is a difference between the two estimators, the Two-step estimates with finite sample corrected standard errors are preferred. The Two-step estimator is furnished with two standard errors in the parentheses. The first pertains to the efficient asymptotic standard error, while the second is derived using the finite sample corrected variance by Windmeijer (2005). As Table 2 suggests, the finite sample corrected standard errors exceed the asymptotic ones and tend to exceed even those of the One-step estimator, which indicates the importance of small sample bias correction (a similar result as in simulations by Windmeijer, 2005). 
Table 1. Data Summary Statistics (cross-section average; in percent)

\begin{tabular}{|c|c|c|c|c|c|}
\hline & 2004 & 2005 & 2006 & 2007 & 2008 \\
\hline \multicolumn{6}{|l|}{ Dependent variable } \\
\hline Credit Default Swap (CDS) (basis points) & 13.8 & 12.3 & 9.6 & 27.3 & 108 \\
\hline Standard deviation of CDS & 3.9 & 3.1 & 2.7 & 17.5 & 47.4 \\
\hline \multicolumn{6}{|l|}{ Capital adequacy } \\
\hline Tier I ratio & 8.3 & 8.1 & 8.3 & 7.9 & 8.4 \\
\hline Tier II ratio & 3.4 & 3.3 & 3.2 & 3 & 3.3 \\
\hline Leverage (multiple of equity) & 25.8 & 27.1 & 27.2 & 27.8 & 31.2 \\
\hline Z-score & 3.5 & 3.5 & 3.8 & 3.7 & 1.9 \\
\hline \multicolumn{6}{|l|}{ Asset quality } \\
\hline Ratio of Loan-loss Provisions to Total Loans & 0.34 & 0.29 & 0.33 & 0.39 & 0.85 \\
\hline Share of Non-performing Loans in Total Loans & 1.88 & 1.8 & 1.75 & 1.68 & 2.3 \\
\hline Loan-Loss Reserves Ratio & 114 & 126 & 106 & 102 & 95 \\
\hline \multicolumn{6}{|l|}{ Management quality } \\
\hline Efficiency Ratio (ratio of operating costs to revenues) & 61.6 & 58.9 & 56.2 & 60.6 & 104.4 \\
\hline Fitch Long-term Issuer Default Rating (numerical scale) & 4.1 & 4.13 & 3.83 & 3.86 & 4.28 \\
\hline Trading income as percent in revenues & 13.98 & 18.61 & 19.38 & 12.98 & -41.24 \\
\hline \multicolumn{6}{|l|}{ Earnings potential } \\
\hline Net Interest Income (percent of average earning assets) & 1.78 & 1.62 & 1.52 & 1.49 & 1.65 \\
\hline $\mathrm{ROA}$ (return on assets) & 0.7 & 0.7 & 0.8 & 0.7 & 0.2 \\
\hline ROE (return on common equity) & 16.32 & 18.1 & 19.86 & 16.49 & 0.19 \\
\hline \multicolumn{6}{|l|}{ Liquidity } \\
\hline Loans to Deposits Ratio & 128 & 134 & 138 & 139 & 150 \\
\hline Short-term Borrowing to Total Liab. & 22 & 22 & 21 & 21 & 20 \\
\hline Wholesale Funds to Total Liab. & 59 & 62 & 63 & 63 & 65 \\
\hline Liquid Assets to Total Assets & 13 & 11.9 & 11.3 & 10.4 & 9.8 \\
\hline \multicolumn{6}{|l|}{ Market risk } \\
\hline Options Impl. Var. of Equity & 16.8 & 18.3 & 21.6 & 25.6 & 52.5 \\
\hline Slope of the Yield Curve & 1.85 & 1.09 & 0.83 & 0.29 & 0.26 \\
\hline Variance of Bank's Equity Price & 99 & 410 & 211 & 497 & 3345 \\
\hline Cost of Funds & 2.4 & 2.5 & 2.9 & 3.5 & 3.3 \\
\hline GDP growth & 2.5 & 2.8 & 3.1 & 3.1 & -1.9 \\
\hline Volatility of GDP growth & 0.41 & 0.55 & 0.45 & 0.5 & 0.15 \\
\hline Weighted GDP growth & 3.9 & 3.5 & 4.2 & 3.97 & 0.15 \\
\hline Volatility of Weighted GDP growth & 0.3 & 0.54 & 0.43 & 0.35 & 0.12 \\
\hline Expected GDP growth & 2.3 & 2.4 & 2.4 & 2.5 & 2.2 \\
\hline Weighted Expected GDP growth & 2.9 & 2.9 & 3 & 3 & 2.9 \\
\hline Moodys' KMV EDF5 & 0.09 & 0.07 & 0.04 & 0.04 & 0.6 \\
\hline VstoXX & 18.9 & 14.1 & 16.5 & 19.7 & 33.7 \\
\hline Bloomberg Euro 500 Stocks Index (index number) & 175 & 202 & 240 & 270 & 202 \\
\hline
\end{tabular}

Source: Bloomberg, Banks' financial statements, EIU, Credit Edge, stoxx.com, and Datastream. 
Table 2. Results: Baseline Model

\begin{tabular}{|c|c|c|c|c|}
\hline & \multicolumn{2}{|c|}{ Unrestricted } & \multicolumn{2}{|c|}{ Parsimonious } \\
\hline & One-step & Two-step & One-step & Two-step \\
\hline \multicolumn{5}{|l|}{ Lagged dependent variable } \\
\hline Credit Default Swap (t-1) & $0.98^{\star \star}(0.41)$ & $1.13^{*}(0.16 ; 0.6)$ & $1.03^{* * \star}(0.25)$ & $1.07^{\star \star \star}(0.1 ; 0.3)$ \\
\hline \multicolumn{5}{|l|}{ Capital adequacy } \\
\hline Leverage & $-0.14(0.33)$ & $-0.26(0.17 ; 0.4)$ & & \\
\hline \multicolumn{5}{|l|}{ Asset quality } \\
\hline Loan-loss Provisions Ratio & $4.22(15.9)$ & $-0.45(5.9 ; 21)$ & & \\
\hline Share of Non-performing Loans & $1.32(2.39)$ & $0.63(1.21 ; 3.6)$ & & \\
\hline \multicolumn{5}{|l|}{ Management quality } \\
\hline Efficiency Ratio & $0.3^{\star \star \star}(0.08)$ & $0.3^{* * \star}(0.05 ; 0.1)$ & $0.31^{* * *}(0.1)$ & $0.3^{* \star *}(0.04 ; 0.1)$ \\
\hline Trading Income Ratio & $0.35^{\star \star \star}(0.08)$ & $0.33^{* * *}(0.05 ; 0.1)$ & $0.36^{\star * *}(0.09)$ & $0.35^{\star \star \star}(0.04 ; 0.1)$ \\
\hline \multicolumn{5}{|l|}{ Earnings potential } \\
\hline Net Interest Income Ratio & $24.2^{* *}(10.2)$ & $23.2^{* *}(4.6 ; 11)$ & $25.2^{\star * \star}(9.3)$ & $25.1^{* *}(3.5 ; 10.5)$ \\
\hline ROA & $-22.8^{*}(11.7)$ & $-21.7^{*}(4 ; 11)$ & $-21^{*}(10.7)$ & $-24.6^{\star \star \star}(2.5 ; 11)$ \\
\hline \multicolumn{5}{|l|}{ Liquidity } \\
\hline Loans to Deposits Ratio & $0.08(0.09)$ & $0.11(0.06 ; 0.13)$ & & \\
\hline \multicolumn{5}{|l|}{ Market risk } \\
\hline Equity Options Implied Volatility & $1.96^{\star * \star}(0.34)$ & $1.86^{\star * *}(0.1 ; 0.3)$ & $2.05^{\star \star \star}(0.3)$ & $1.92^{* * *}(0.08 ; 0.3)$ \\
\hline Slope of the Yield Curve & $-11.5^{\star * \star}(3.9)$ & $-12^{* \star}(2.6 ; 5.2)$ & $-12.5^{\star \star \star}(3.1)$ & $-11.5^{\star \star \star}(0.9 ; 2.6)$ \\
\hline Bloomberg Euro 500 Stocks Index & $0.01(0.07)$ & $-0.01(0.02 ; 0.05)$ & & \\
\hline \multicolumn{5}{|l|}{ Test statistics } \\
\hline $1^{\text {st }}$ order autocorrelation & $-2.6^{\star * \star}(0.01)$ & $-1.64^{*}(0.1)$ & $-2.04^{* *}(0.04)$ & $-1.79^{*}(0.07)$ \\
\hline $2^{\text {nd }}$ order autocorrelation & $1.3(0.18)$ & $0.97(0.33)$ & $1.35(0.18)$ & $0.99(0.32)$ \\
\hline Hansen test of overid. restrictions & $20.2(0.26)$ & $20.2(0.26)$ & $23.2(0.39)$ & $23.2(0.39)$ \\
\hline Number of observations / Banks & $87 / 29$ & $87 / 29$ & 87 / 29 & 87 / 29 \\
\hline F-Test (for joint insignificance) & - & - & $0.03(0.99)$ & $0.65(0.66)$ \\
\hline $\mathrm{R}^{2}$ & 0.9 & 0.9 & 0.9 & 0.89 \\
\hline
\end{tabular}

Notes: Standard errors for coefficients and probabilities for Test statistics are given in parentheses. The Two-step estimates contain both the asymptotic (the first one) and the Windmeijer's (2005) finite sample corrected standard errors. Stars denote significance level as follows: ${ }^{*} 10 \%$, ${ }^{* *} 5 \%,{ }^{* * *} 1 \%$. Inference in Two-step estimates is based on the finite sample corrected standard errors. Test statistics in the Two-step estimator pertain to the regression with finite sample corrected variance. Instruments contain the GMM style regressors (2nd and 3rd lag) of the lagged dependent variable, ROA, GDP growth, expected GDP growth by Consensus Forecasts and further the lagged differenced Leverage, Tier I, Tier II, Loan-loss Provisions Ratio, the Share of Non-performing Loans, Efficiency Ratio, the Share of Trading Income in Revenues, the Slope of the Yield Curve, Net Interest Income Ratio, and Loans to Deposits Ratio. 
31. The instruments are valid and the estimation does not suffer from serial correlation in residuals. The validity of instruments is tested using Hansen test of over-identifying restrictions - a preferred statistic for estimation with robust standard errors. The test does not reject the validity of instruments on the 26 percent significance level. Further, as expected the presence of the first order serial correlation is not rejected, while the second order autocorrelation is (probabilities 0.18 and 0.33 for One- and Two-step estimator, respectively). The latter one implies no problems with serial correlation.

32. The results confirm the dynamic specification and underline management quality, earnings potential, and market risk as significant determinants of CDS spread. The CDS spread turns out to be close to a random walk - the persistence is not statistically different from unity. Six other variables turned out to be significant determinants of the CDS spread: the Efficiency Ratio, Trading Income Ratio, Net Interest Income Ratio, ROA, the Implied Volatility, and the Slope of the Yield Curve. While the management and earnings indicators describe the bank's business model, the market risk indicators condense the expectations about the future.

- A more risky business increases the CDS spread, while operating cost reductions, better revenues, and ROA lower it. A percentage increase in the share of income from trading and from net interest margin increases the CDS spread by 0.33 bps and $23.2 \mathrm{bps}$, respectively. A percentage reduction in the ratio of cost to revenues lowers the CDS spread by 0.3 bps, while an increase in ROA by 1 percent lowers the spread by 21.7 bps.

- An elevated market risk increases CDS spreads. A percentage increase in Options Implied Volatility, which signals greater uncertainty about banks' equity, increases the CDS spread by 1.86 bps. Similarly, a percentage decrease in the Slope of the Yield Curve increases the CDS spread by 12 bps.

33. On the other hand, other key financial soundness indicators, such as capital adequacy, asset quality, and liquidity turn out to be insignificant. The insignificance of capital adequacy and liquidity likely stems from the very little variation in leverage (the capital measure used in the estimation) and loan-to-deposit ratio (the liquidity measure used in the estimation), respectively, within the LCFIs group during the sample period. The sample period is likely a reason for insignificance of the asset quality indicators (Loan-loss Provisions and the Share of Nonperforming Loans) as well. The sample period covers only the outbreak of the crisis and as such does not include yet the adverse effect on the loan portfolio.

34. The model fits the data well. The $\mathrm{R}^{2}$ statistic presented in Table 2 is computed on first differences over the three-year estimation period during 2006-2008 and reaches about 89 percent. The lagged dependent variable and the market risk indicators contribute 37 percent each, while the management and earnings potential (financial soundness indicators) account jointly for 16 percent. 
35. A baseline parsimonious model has been derived by dropping insignificant variables in the unrestricted model. According to the performed F-test, all insignificant variables in the unrestricted baseline specification can be excluded from the model. The probability of not rejecting the joint restriction is 0.99 for One-step estimator and 0.66 for the Two-step estimator. The results in the parsimonious baseline model remain robust to the restrictions and are used in the robustness analyses, which follow in the next two sections.

\section{B. Robustness to Alternative CAMEL Indicators}

36. The parsimonious baseline specification showed robustness to a wide range of alternative financial soundness indicators and time dummy for the crisis year 2008 . For the same categories of financial soundness indicators, nine alternative variables across the CAMEL structure were used: Tier I, Tier II, Z-score (for capital adequacy), Loan-loss Reserves (for asset quality), Long-term Issuer Default Rating (for management quality), ROE (for earnings potential), and Short-term Borrowing to Total Liabilities, Wholesale Funds to Total Liabilities, and the ratio of Liquid Assets to Total Assets (for liquidity). In addition, the CDS market in 2008 (especially in the second half) was possibly driven by factors outside the baseline model and thus a dummy for that year was tested (A10). The baseline model specification proved robust to all alternative CAMEL indicators as well as to the dummy variable for 2008.

\section{The diagnostic estimations confirm validity of instruments and no autocorrelation}

problems in all ten regressions. Table 3 displays the results for the Two-step estimator with Windmeijer's (2005) standard errors in parentheses. The Hansen test of over-identifying restrictions never rejects the validity of instruments at conventional significance levels. The set of instruments has been adjusted in several regressions. The adjustments are listed in the notes to the Table 3. The tests for serial correlation show a significant first order and insignificant second order autocorrelation - a required serial correlation structure by the theory.

38. The alternative measures of capital adequacy are statistically insignificant and point to a homogeneity of LCFIs in capitalization. The regression results (A1-A3) show the effects of the alternative capital adequacy specifications - the Tier I, Tier II, and Z-score, respectively. None of the three indicators adds additional explanatory power to the parsimonious baseline specification. Their insignificance is likely caused by high sample homogeneity in capital adequacy measures that remain rather stable during the initial crisis years.

39. Moreover, the alternative measures of asset quality, management quality, and earnings potential also do not add value to the baseline model. The regression results (A4A6) test the significance of Loan-loss Reserves Ratio, Long-term Issuer Default Rating, and ROE, respectively. The insignificance of the Loan-loss Reserves Ratio and the Long-term Issuer Default Rating is again most likely caused by the LCFIs' homogeneity and stability of reserves 
and the rating during the outbreak of the crisis. In the case of ROE, its insignificance is a result of its subordinate information content compared to ROA.

40. Alternative liquidity measures show mixed results. The results for the baseline regression containing Short-term Borrowing to Total Liabilities, Wholesale Funds to Total Liabilities, and Liquid Assets in Total Assets, respectively are contents of the columns A7-A9. While the share of liquid assets in total assets and the share of wholesale funds in total liabilities turn out to be insignificant, a higher share of short-term borrowing in total liabilities is associated with a higher CDS spread and is marginally statistically significant. However, its contribution to the baseline's overall explanatory power is negligible. 
Table 3. Results: Two-step Estimates of the Baseline with Alternative CAMEL Indicators

\begin{tabular}{|c|c|c|c|c|c|c|c|c|c|c|}
\hline & A1 & A2 & $\mathrm{A} 3^{1 /}$ & $\mathrm{A} 4^{21}$ & A5 & A6 & $\mathrm{A} 7^{3 /}$ & $\mathrm{A} 8^{4 /}$ & $\mathrm{A}^{5 /}$ & A10 \\
\hline \multicolumn{11}{|l|}{ Lagged dependent variable } \\
\hline Credit Default Swap (t-1) & $0.9^{\star \star \star}(0.3)$ & $1.2^{\star \star \star}(0.3)$ & $1.0^{* * *}(0.2)$ & $1.0^{* \star \star}(0.3)$ & $1.1^{* \star *}(0.3)$ & $1.1^{* \star *}(0.3)$ & $0.9^{\star \star \star}(0.2)$ & $1.0^{\star \star \star}(0.2)$ & $1.0^{\star * \star}(0.2)$ & $1.1^{\star \star \star}(0.3)$ \\
\hline \multicolumn{11}{|l|}{ Capital adequacy } \\
\hline Tier I & $-1.4(2.8)$ & & & & & & & & & \\
\hline Tier ॥ & & $-3.9(5.2)$ & & & & & & & & \\
\hline Z-score & & & $-0.87(2.4)$ & & & & & & & \\
\hline \multicolumn{11}{|l|}{ Asset quality } \\
\hline Loan-loss Reserves Ratio & & & & $0.03(0.04)$ & & & & & & \\
\hline \multicolumn{11}{|l|}{ Management quality } \\
\hline Efficiency Ratio & $0.3^{\star \star}(0.1)$ & $0.3^{\star \star}(0.1)$ & $0.3^{* * *}(0.1)$ & $0.3^{\star \star \star}(0.08)$ & $0.3^{\star \star}(0.12)$ & $0.3^{\star * *}(0.1)$ & $0.3^{\star \star \star}(0.1)$ & $0.3^{\star \star}(0.12)$ & $0.3^{* * *}(0.1)$ & $0.3^{\star \star \star}(0.1)$ \\
\hline Trading Income Ratio & $0.3^{\star \star \star}(0.1)$ & $0.3^{\star \star \star}(0.1)$ & $0.4^{\star \star *}(0.1)$ & $0.3^{\star \star \star}(0.08)$ & $0.4^{* \star *}(0.1)$ & $0.4^{\star * \star}(0.1)$ & $0.36^{\star \star \star}(0.1)$ & $0.3^{\star \star *}(0.1)$ & $0.3^{\star \star \star}(0.1)$ & $0.35^{\star \star \star}(0.1)$ \\
\hline Long-term Issuer Default Rating & & & & & $-2.7(7.6)$ & & & & & \\
\hline \multicolumn{11}{|l|}{ Earnings potential } \\
\hline Net Interest Income Ratio & $23^{*}(12.5)$ & $21.5^{\star *}(10)$ & $20.3^{*}(10.8)$ & $26.3^{* * *}(9.9)$ & $24.6^{\star \star}(12)$ & $24.4^{\star *}(11)$ & $21^{* \star}(10.1)$ & $19.7^{*}(12)$ & $20.1^{*}(10)$ & $25.9^{\star *}(11.7)$ \\
\hline ROA & $-22.8^{*}(13)$ & $-22.3^{\star \star}(11)$ & $-30.7^{* \star *}(10)$ & $-20.4^{*}(11.4)$ & $-25.8^{* *}(12)$ & $-34.6^{* \star}(16)$ & $-31.1^{* * *}(11)$ & $-29.4^{* *}(12)$ & $-34^{* * *}(10.1)$ & $-23.1^{* \star}(11.2)$ \\
\hline ROE & & & & & & $0.45(0.36)$ & & & & \\
\hline \multicolumn{11}{|l|}{ Liquidity } \\
\hline Short-term Borrowing to Total Liab. & & & & & & & $0.45^{\star}(0.23)$ & & & \\
\hline Wholesale Funds to Total Liab. & & & & & & & & $0.06(0.39)$ & & \\
\hline Liquid Assets to Total Assets & & & & & & & & & $0.26(0.66)$ & \\
\hline \multicolumn{11}{|l|}{ Market risk } \\
\hline Options Impl. Var. of Equity & $2.1^{* \star \star}(0.4)$ & $1.9^{\star \star \star}(0.4)$ & $1.8^{\star \star \star}(22)$ & $2.04^{\star \star *}(0.3)$ & $2^{* \star *}(0.3)$ & $1.9^{* * *}(0.3)$ & $1.95^{\star \star \star}(0.2)$ & $1.9^{* * *}(0.4)$ & $1.8^{* * *}(0.3)$ & $1.9^{\star \star \star}(0.4)$ \\
\hline Slope of the Yield Curve & $-10.7^{\star * \star}(3)$ & $-11.5^{\star \star \star}(3)$ & $-10.3^{\star \star \star}(2)$ & $-11.9^{* \star *}(3)$ & $-11.6^{\star \star \star}(3)$ & $-12^{\star \star \star}(3)$ & $-10^{\star * \star}(2.1)$ & $-10^{\star \star \star}(3.1)$ & $-10.6^{\star \star *}(3)$ & $-11.7^{\star \star \star}(2.8)$ \\
\hline Dummy (year 2008) & & & & & & & & & & $0.6(10.5)$ \\
\hline \multicolumn{11}{|l|}{ Test statistics } \\
\hline $1^{\text {st }}$ order autocorrelation & $-1.7^{*}(0.09)$ & $-1.8^{*}(0.07)$ & $-1.8^{*}(0.07)$ & $-1.7^{\star}(0.09)$ & $-1.8^{*}(0.07)$ & $-1.9^{*}(0.06)$ & $-1.66^{*}(0.1)$ & $-1.8^{*}(0.07)$ & $-1.8^{*}(0.07)$ & $-1.8^{*}(0.08)$ \\
\hline $2^{\text {nd }}$ order autocorrelation & $0.96(0.33)$ & $0.96(0.34)$ & $1.1(0.26)$ & $0.8(0.43)$ & $1.27(0.2)$ & $1.44(0.15)$ & $0.66(0.51)$ & $1.05(0.29)$ & $0.85(0.4)$ & $1.0(0.3)$ \\
\hline Hansen test of overid. restrictions & $23.1(0.34)$ & $24.7(0.26)$ & $17.9(0.65)$ & $22.8(0.36)$ & $23.2(0.33)$ & $22.7(0.36)$ & $18.1(0.64)$ & $17.6(0.67)$ & $17.9(0.66)$ & $22.7(0.4)$ \\
\hline Number of observations / Banks & $87 / 29$ & $87 / 29$ & $87 / 29$ & $87 / 29$ & $87 / 29$ & $87 / 29$ & $87 / 29$ & $87 / 29$ & $87 / 29$ & $87 / 29$ \\
\hline $\mathrm{R}^{2}$ & 0.89 & 0.9 & 0.9 & 0.9 & 0.89 & 0.89 & 0.88 & 0.88 & 0.88 & 0.89 \\
\hline
\end{tabular}

Notes: The Windmeijer's (2005) finite sample corrected standard errors for coefficients and probabilities for Test statistics are given in parentheses. Stars denote significance level as follows: ${ }^{*} 10 \%,{ }^{* *} 5 \%,{ }^{* * *} 1 \%$. If not specified otherwise, instruments contain the GMM style regressors (2nd and 3rd lag) of the lagged dependent variable, ROA, GDP growth, GDP forecast by Consensus Forecasts and further the lagged differenced Leverage, Tier I, Tier II, Loan-loss Provisions Ratio, the Share of Non-performing Loans, Efficiency Ratio, the Share of Trading Income in Revenues, the Slope of the Yield Curve, Net Interest Income Ratio, and Loans to Deposits Ratio.

1/ Liquid assets over total assets replaced the Loans over deposits instrument. 2/ Loan-loss reserves to non-performing loans replaced the share of non-performing loans. 3/ Short-term borrowing to total liabilities replaced loans to deposits ratio. 4/ Wholesale funds to total liabilitiesd replaced loans to deposits ratio. 5 / Liquid assets to total assets replaced the loans to deposits ratio. 


\section{Robustness to Alternative Market Risk Indicators}

41. The parsimonious baseline specification is fairly robust, and explains a dominant portion of CDS spread variability under alternative market risk indicators. The baseline was tested against the following nine market risk variables: the Historical Variance of Bank's Equity Price, Moody's KMV EDF5, the Cost of Funds, Actual and Expected GDP growth, Actual and Expected GDP growth weighted by bank's revenues, the Volatility of GDP growth and of Weighted GDP growth. Most of the variables turned out to be insignificant and those that were significant added a negligible explanatory power to the baseline model.

42. The diagnostics of the Two-step estimator, presented in Table 4, confirm robust estimation results in all nine regressions. The validity of instruments has not been rejected by Hansen test of over-identifying restrictions at conventional significance levels. The second order autocorrelation is rejected in all nine regressions. The absence of the first order autocorrelation in the regression A19 is only marginal and is secondary to the importance of the second order autocorrelation test.

- Most alternative market risk indicators turn out to be statistically insignificant. The historical Variance of Bank's Equity Price is insignificant, while Moody's KMV EDF5 correlates positively with the CDS spread. The historical variance of equity (regression A11) appears to carry lower information content than the implied volatility from options, which is statistically significant in the baseline model. On the other hand, a percentage increase in EDF5 (mixing the equity price and its implied volatility) leads to a rise in the CDS spread by 5.2 percent (regression A19), but the contribution to the coefficient of determination is negligible.

- The Cost of Funds turns out to be not a significant yardstick in credit risk for the LCFIs, suggesting that the LCFIs form a group of homogenous entities that have similar access to funds (regression A12).

- Weighted GDP growth and its volatility show better results than those of the country of LCFI's incorporation. The GDP growth of the parent bank's country and its volatility are statistically insignificant (regressions A13 and A14). While it is also insignificant, Weighted GDP growth has a negative sign, which is in line with theory (regression A15). In addition, the Volatility of GDP growth is marginally significant and positive (i.e., a percentage increase in volatility implies an increase in CDS spread by 4.8 percent, regression A16). Nevertheless, also in this case, the explanatory power added by this variable to the baseline model is negligible.

- $\quad$ Expected GDP growth and stock market volatility turned out to be uninformative (regressions A17, A18, and A20). Even though banks, in their operations, depend, to a significant extent, on the accuracy of GDP forecasts, the forecasts (both expected GDP 
growth and weighted (effective) Expected GDP growth) turn out to be insignificant in explaining CDS spreads. Similarly, European stock market volatility (VSTOXX) was insignificant, likely being dominated by highly significant bank-specific implied volatility from options. 
Table 4. Results: Two-step Estimates of the Baseline with Alternative Market Risk Indicators

\begin{tabular}{|c|c|c|c|c|c|c|c|c|c|c|}
\hline & A11 & A12 & $\mathrm{A} 13^{1 /}$ & $\mathrm{A} 14^{2 /}$ & $\mathrm{A} 15^{3 /}$ & $\mathrm{A} 16^{4 /}$ & $\mathrm{A} 17^{5 /}$ & $\mathrm{A} 18^{5 /}$ & $\mathrm{A} 19^{4,6 /}$ & A20 \\
\hline \multicolumn{11}{|l|}{ Lagged dependent variable } \\
\hline Credit Default Swap (t-1) & $0.99^{* * *}(0.2)$ & $1.09^{* * *}(0.3)$ & $0.9^{\star \star *}(0.3)$ & $1.15^{\star \star}(0.5)$ & $1.2^{\star \star \star}(0.3)$ & $0.99^{\star * *}(0.3)$ & $1.17^{\star * *}(0.3)$ & $1.4^{\star \star \star}(0.4)$ & $1.17^{* * *}(0.3)$ & $1.1^{* * *}(0.3)$ \\
\hline \multicolumn{11}{|l|}{ Management quality } \\
\hline Efficiency Ratio & $0.29^{\star \star \star}(0.1)$ & $0.31^{* \star}(0.14)$ & $0.26^{* *}(0.1)$ & $0.29^{\star \star \star}(0.1)$ & $0.28^{*}(0.1)$ & $0.3^{* * *}(0.1)$ & $0.28^{\star * *}(0.1)$ & $0.24^{* *}(0.1)$ & $0.3^{* *}(0.11)$ & $0.3^{* *}(0.11)$ \\
\hline Trading Income Ratio & $0.33^{* * *}(0.1)$ & $0.35^{* * *}(0.1)$ & $0.33^{* \star *}(0.1)$ & $0.3^{* * *}(0.1)$ & $0.3^{*}(0.16)$ & $0.34^{* * *}(0.1)$ & $0.33^{* * *}(0.1)$ & $0.3^{* \star}(0.1)$ & $0.3^{* \star *}(0.1)$ & $0.34^{* *}(0.1)$ \\
\hline \multicolumn{11}{|l|}{ Earnings potential } \\
\hline Net Interest Income Ratio & $20.6^{*}(10.3)$ & $25.5^{\star}(14.9)$ & $24.8^{* *}(10)$ & $23.7^{* \star}(10.3)$ & $18.2^{*}(9.6)$ & $21.3^{*}(12)$ & $22.1^{*}(12)$ & $21^{* *}(8.9)$ & $17.4^{*}(9.4)$ & $23.3^{*}(13)$ \\
\hline $\mathrm{ROA}$ & $-31.7^{\star * \star}(9.7)$ & $-23.8^{* *}(11.1)$ & $-36.1^{* * *}(13)$ & $-31.2^{* * *}(10)$ & $-21(14)$ & $-29.7^{* * *}(11)$ & $-28^{* * *}(6.4)$ & $-29.4^{\star * *}(7)$ & $-29.4^{* * *}(8)$ & $-24.1^{\star \star}(10.5)$ \\
\hline \multicolumn{11}{|l|}{ Market risk } \\
\hline Options Impl. Var. of Equity & $1.8^{\star \star \star}(0.25)$ & $1.92^{* * *}(0.3)$ & $1.8^{* * *}(0.3)$ & $1.8^{\star \star \star}(0.6)$ & $1.7^{\star * *}(0.3)$ & $1.9^{* \star \star}(0.3)$ & $1.9^{\star \star \star}(0.22)$ & $1.7^{* * \star}(0.3)$ & $1.7^{\star \star *}(0.4)$ & $1.8^{\star * *}(0.6)$ \\
\hline Slope of the Yield Curve & $\begin{array}{c}-10.4^{* \star *}(1.9) \\
.0002\end{array}$ & $-11.3^{* \star}(4.7)$ & $-11.8^{* \star *}(3.3)$ & $-11.8^{* \star *}(1.2)$ & $-10.6^{\star * *}(3.1)$ & $-11.3^{\star \star \star}(2.2)$ & $-7.46^{\star *}(3.4)$ & $-9.9^{\star * *}(2.2)$ & $-11^{* \star *}(3.3)$ & $-10.3^{*}(5.7)$ \\
\hline Variance of Bank's Equity Price & $(.0001)$ & & & & & & & & & \\
\hline Cost of Funds & & $30.2(464)$ & & & & & & & & \\
\hline GDP growth & & & $0.007(0.8)$ & & & & & & & \\
\hline Volatility of GDP growth & & & & $3.1(4.4)$ & & & & & & \\
\hline Weighted GDP growth & & & & & $-1.4(2.5)$ & & & & & \\
\hline Volatility of Weighted GDP growth & & & & & & $4.8^{*}(2.4)$ & & & & \\
\hline Expected GDP growth & & & & & & & $10.4(10)$ & & & \\
\hline Weighted Expected GDP growth & & & & & & & & $15.4(10)$ & & \\
\hline Moodys' KMV EDF5 & & & & & & & & & $5.2^{\star \star \star}(2)$ & \\
\hline vSTOXX & & & & & & & & & & $0.3(1.1)$ \\
\hline \multicolumn{11}{|l|}{ Test statistics } \\
\hline $1^{\text {st }}$ order autocorrelation & $-1.9^{*}(0.06)$ & $-1.79^{*}(0.07)$ & $-1.7^{\star}(0.09)$ & $-1.62^{*}(0.1)$ & $-1.67^{\star}(0.1)$ & $-1.75^{*}(0.08)$ & $-1.76^{*}(0.08)$ & $-1.8^{*}(0.07)$ & $-1.52(0.13)$ & $-1.9^{*}(0.06)$ \\
\hline $2^{\text {nd }}$ order autocorrelation & $1.25(0.2)$ & $0.82(0.42)$ & $0.56(0.58)$ & $0.84(0.4)$ & $1.29(0.2)$ & $0.88(0.38)$ & $1.11(0.27)$ & $0.82(0.41)$ & $0.56(0.58)$ & $0.99(0.33)$ \\
\hline Hansen test of overid. restrictions & $18.1(0.64)$ & $23.6(0.32)$ & $19.6(0.55)$ & $20.7(0.48)$ & $20.2(0.51)$ & $19.86(0.53)$ & $15.35(0.81)$ & $15.9(0.77)$ & $19.9(0.53)$ & $23.7(0.3)$ \\
\hline Number of observations / Banks & $87 / 29$ & $87 / 29$ & $87 / 29$ & $87 / 29$ & $87 / 29$ & $87 / 29$ & $87 / 29$ & $87 / 29$ & $87 / 29$ & $87 / 29$ \\
\hline $\mathrm{R}^{2}$ & 0.88 & 0.89 & 0.87 & 0.88 & 0.9 & 0.89 & 0.88 & 0.87 & 0.9 & 0.89 \\
\hline
\end{tabular}

Notes: The Windmeijer's (2005) finite sample corrected standard errors for coefficients and probabilities for Test statistics are given in parentheses. Stars denote significance level as follows: * $10 \%,{ }^{*} 5 \%,{ }^{* * *} 1 \%$. If not specified otherwise, instruments contain the GMM style regressors (2nd and 3rd lag) of the lagged dependent variable, ROA, GDP growth, GDP forecast by Consensus Forecasts and further the lagged differenced Leverage, Tier I, Tier II, Loan-loss Provisions Ratio, the Share of Non-performing Loans, Efficiency Ratio, the Share of Trading Income in Revenues, the Slope of the Yield Curve, Net Interest Income Ratio, and Loans to Deposits Ratio.

1/ Weighted GDP growth replaced GDP growth instrument. 2/Variance of GDP growth replaced the loans to deposits ratio. 3/Volatility of weighted GDP growth replaced the expected GDP growth. In addition, the ratio of Liquid assets over total assets replaced the Loans over deposits instrument. 4/Volatility of weighted GDP growth replaced the Loans to Deposits Ratio. 5/ Liquid assets to total assets replaced the loans to deposits ratio. 6/ EDF replaced the GDP growth instrument. 


\section{Concluding Remarks And Policy Implications}

\section{This paper exclusively focuses on, and provides a specific treatment of, LCFIs,} which is unique in the literature on bank failures that tends to exclude LCFIs. In particular, Barr and Siems (1994) exclude banks that exceed \$300 million in total assets, arguing that such large banks are usually under much stricter supervision than mid-size banks. Wheelock and Wilson (2000) exclude banks that operate foreign branches and restrict the analysis to pure commercial banks. The paper's findings therefore add to the literature analyzing bank failures.

\section{The key finding of the paper is that LCFIs' business models, earnings potential,} and economic uncertainty are among the most significant determinants of credit risk. Based on annual data for European LCFIs, the results suggest that more vulnerable LCFIs (reflected in their higher CDS spreads) tend to exhibit a higher net interest rate margin, a higher share of trading income, a higher cost efficiency ratio (as measured by operating expenses-to-total revenue), a higher share of short-term borrowing in total liabilities, and lower ROA, compared to banks with lower CDS spreads. Economic uncertainty (represented by market expectations about the future risks of a particular LCFI, as well as market views on prospects for economic growth) also explains LCFIs' CDS spreads. The results are mostly driven by cross-sectional variability in the CDS spread during the current crisis. In the period of financial crisis, markets seem to have discriminated across LCFIs that were hit to various degrees, which increased the cross-sectional variability and allowed for statistically significant identification of CDS pricing mechanism used by the markets.

\section{The findings of the paper are broadly consistent with those of the literature on bank failure, where the determinants of the latter include the entire CAMELS} structure. While the LCFIs' default risk appears not to be explicitly linked in the estimations to banks' capital adequacy and asset quality (the first two factors in the CAMELS structure), ${ }^{9}$ market expectations about the future risks of an LCFI (based on implied volatility from options) and market views on economic growth prospects (slope of the yield curve), which are statistically significant, contain expectations about the future value of banks (equity capital) and economic outlook (with its impact on asset quality). Therefore, the default risk of LCFIs seems to be related to the entire structure of the CAMELS, consistent with the bank failure literature. ${ }^{10}$

\footnotetext{
${ }^{9}$ The statistical insignificance of bank capitalization and asset quality in gauging the credit risk of LCFIs might stem from the specific period of analysis. It is intuitive that the business model is a relevant descriptor of the credit default risk during the outbreak of the crisis. Earnings and risk taking are the core factors that affect bank capital and determine its value. The fact that capital adequacy or asset quality does not make a difference in the pricing of CDS for LCFI might hence be attributed to the period of analysis that covers the start of the crisis only. Measures of asset quality (e.g., non-performing loans) reveal credit risk with a lag.

${ }^{10}$ The differences between the two strands of literature (estimating the CDS of LCFIs and bank failure) might be reconciled by the role of expectations. The statistically significant forward-looking variables (slope of the
} 
46. The comparison with European bank distress literature paints a similar picture - distress determinants cover the entire CAMELS. Poghosyan and Cihak (2009), working with a large sample of banks in Europe over mid-1990 till 2008 and defining a media driven bank distress variable, find that bank distress is linked to capitalization, asset quality, earnings, liquidity, market risk (stock market), and the cost of funds. Similarly, Kick and Koetter (2007), using a large sample of German banks during 1995-2004, find as significant the following distress variables: capital adequacy, asset quality, cost efficiency, earnings, liquidity, and market risk (corporate insolvency rate).

47. The paper's findings also suggest that overall; most variables suggested by the structural approach to the pricing of default risk are significant determinants of the LCFIs' CDS spreads. The slope of the yield curve and implied volatility from option prices proved to be significant determinants of LCFIs' CDS spreads, consistent with the findings in the literature (Ericsson et al., 2009; Abid and Naifar, 2006; Blanco et al., 2005, Aunon-Nerin et al., 2002). Leverage, however, is not significant, due to its high persistence and little variation across the LCFIs during the sample period.

48. By establishing a link between the financial and market fundamentals of LCFIs and their CDS spreads, the paper offers a potential tool for fundamentals-based monitoring of LCFIs. The need for such tools has been amplified by the potential systemic risk LCFIs can generate for domestic financial sectors as well as those across borders where such LCFIs operate. The CDS spread contains information about the probability of default given the recovery rate and, hence, the determinants of CDS spreads for LCFIs could provide information about the extent of their vulnerability.

49. The identified CDS pricing mechanism can then be potentially used for vulnerability assessment and as an early warning tool. An out of sample forecast for statistically significant CDS spread determinants of LCFIs would produce forward looking credit default risk assessment of their financial vulnerability in cross-section and time dimension. This could be possibly done even for banks that do not have a CDS spread.

50. It should be noted however that the analysis has been limited to European LCFI in order to preserve high degree of sample homogeneity, and extrapolation of results to other banks and countries might require adjustments. The analysis focused on European LCFIs because most LCFIs that have CDS spreads covering 2004-008 are domiciled in Europe. The results thus pertain to European LCFIs and transferability of the identified pricing mechanism to other banks in other regions requires caution. Even though the connecting mechanism across markets and countries is the common investor base, banks in

yield curve and implied volatility) driving CDS spreads are variables usually missing in CAMELS bank failure and distress models, and likely contain expectations about the impact of the crisis on asset quality and equity capital. 
other regions might not be homogenous in terms of cost of funds and other aspects to the same degree as the European sample of LCFIs. In addition, some adjustments may be needed in using the identified pricing mechanism to evaluate banks that do not have CDS spreads. 


\section{APPENDIX I. CDS Spreads and LCFI Interventions}

Table 5. Interventions in European LCFI in the sample (2008/9-2009/5)

\begin{tabular}{|c|c|c|c|}
\hline Financial institution & Measure & $\begin{array}{l}\text { Percent } \\
\text { of total } \\
\text { assets }\end{array}$ & $\begin{array}{l}\text { CDS in bps. } \\
\text { (avg. of } 30 \\
\text { days before } \\
\text { intervention) }\end{array}$ \\
\hline Dexia SA & $€ 6.4$ bn capital (Sep 30, 2008) & 1.0 & 62 \\
\hline UBS AG & \$54bn liquidity (Oct 16, 2008) & 2.7 & 236 \\
\hline Royal Bank of Scotland & $\approx £ 33$ bn capital $($ Oct 19,2008$)$ & 1.4 & 206 \\
\hline Lloyds & $£ 4$ bn capital $($ Oct 19,2008$)$ & 0.9 & 138 \\
\hline Credit Agricole & $€ 3$ bn capital (Oct 22,2008$)$ & 0.2 & 91 \\
\hline BNP Paribas & $€ 2.55$ bn capital (Oct 22, 2008) & 0.1 & 69 \\
\hline Societe Generale & $€ 1.7 \mathrm{bn}$ capital (Oct 22,2008$)$ & 0.2 & 100 \\
\hline Erste Group Bank & $€ 2.7 \mathrm{bn}$ capital $($ Oct 30,2008$)$ & 1.3 & 186 \\
\hline Commerzbank & $€ 8.2 \mathrm{bn}$ capital $\& € 15 \mathrm{bn}$ guarantees (Nov 4,2008$)$ & 1.3 & 82 \\
\hline Anglo-Irish Bank & $€ 1.5$ bn capital (Dec 21,2008$)$ & 1.5 & 187 \\
\hline Commerzbank & $€ 10$ bn capital (Jan 7, 2009) & 1.6 & 85 \\
\hline Raiffeisen Zentralbank & $€ 1.75$ bn capital (Jan 30, 2009) & 2.0 & 240 \\
\hline Royal Bank of Scotland & $£ 325$ bn liquidity; £19bn capital (Feb 26, 2009) & 0.8 & 155 \\
\hline Unicredit SPA & $€ 4$ bn capital (March18, 2009) & 0.4 & 228 \\
\hline Intesa Sanpaolo & $€ 4$ bn capital (March 20, 2009) & 0.6 & 170 \\
\hline Monte dei Paschi di Siena & $€ 1.9$ bn capital (March 27, 2009) & 0.9 & 142 \\
\hline BNP Paribas & $€ 5.1$ bn capital (March 31, 2009) & 0.2 & 113 \\
\hline Natixis & $€ 5$ bn capital (May 13,2009 ) & 0.9 & 288 \\
\hline
\end{tabular}

Source: IMF, Bloomberg, and own calculations. 


\section{APPENDIX II. Fundamental Risk from LCFI's Risk-Return Profile}

This appendix provides motivation for the choice of fundamental determinants in the baseline regression specification. Banking business can be viewed as a leveraged portfolio management since banks leverage on depositors and invest in risky projects. Therefore, the level of the banks' credit default risk and thus the premium charged on Credit Defaults Swaps (CDS) contracts hinges on the level of risk in the bank's portfolio and on the effective balance between risk and return. Banks minimize the following objective function

$$
\begin{aligned}
& \operatorname{Min}_{w_{j}, i_{j}, F, A}\left\{\sum_{j=1}^{N} w_{j} \sigma_{j}-q\left[\sum_{j=1}^{N} w_{j} i_{j}+F-P-C(A)\right](1-\tau)\right\}, \\
& \text { S.t. } \sum_{j=1}^{N} w_{j} i_{j}+F-P-C(A) \geq 0 \\
& i_{j}=\sigma_{j} \frac{1-\emptyset_{j}}{E\left(1-\emptyset_{j}\right)} \\
& C^{\prime}(.)>0 ; \sum_{j=1}^{N} w_{j}=1 ; F \leq F^{*} ; P=f\left(\Delta \emptyset_{j}\right)
\end{aligned}
$$

by choosing $w_{j}$ (weight of asset $j$ in the portfolio), $i_{j}$ which stands for the interest rate margin on asset $j$ (a return on asset less the interest rate paid on borrowed funds), fees per dollar of assets $F$, and the size of assets $A$. Decisions are primarily constraint by a break-even condition and the pricing mechanism of risky projects that links $i_{j}$ to the risk premium $\sigma_{j}$, the share of impaired assets $\emptyset_{j}$, and the expected default rate $E\left(\varnothing_{j}\right)$. A cap on fees per dollar of assets $F^{*}$ and the cost function $C($.$) are additional restrictions stemming from competitive$ markets. There are $N$ assets. The risk tolerance is denoted by letter $q$ and $P$ stands for provisions for impaired assets relative to total assets. The coefficient $\tau$ denotes the applicable tax rate.

Further, let $i_{N}$ be the rate of return from trading. Securities designated for trading are meant to generate short-term income and are purchased with the intention of a quick resale at a profit (fair value of traded securities is recognized each quarter). Therefore, assuming that the return from trading is more volatile, the rate of return from trading relative to the rest of the portfolio $\omega$ would proxy the trading risk surcharge over the rest of the portfolio. The regression specification for the baseline model of CDS pricing results by writing the bank's risk objective function along with the break-even condition (and Lagrange multiplier $\lambda$ ):

$$
C D S=c+\alpha i+\beta \omega-q R O A+\lambda E F F,
$$

where $\mathrm{c}=-\lambda, R O A=\left[\sum_{j=1}^{N} w_{j} i_{j}+F-P-C(A)\right](1-\tau), E F F=\frac{P+C(A)}{\sum_{j=1}^{N} w_{j} i_{j}+F}, i=$ $\sum_{j=1}^{N-1} w_{j} i_{j} /\left(1-w_{N}\right), \omega=\frac{w_{N} i_{N}}{\sum_{j=1}^{N} w_{j} i_{j}+F}$, and $\alpha, \beta, q, \lambda$ are sensitivities to risks by the market. 


\section{REFERENCES}

Abid, Fathi, Nader Naifar, 2006, "The Determinants of Credit Default Swap Rates: An Explanatory Study," International Journal of Theoretical and Applied Finance, Vol. 9 (Issue 1), pp. 23-42.

Arellano, Manuel, Stephen Bond, 1991, "Some tests of Specification for Panel Data: Monte Carlo Evidence and an Application to Employment Equations," Review of Economic Studies, Vol. 58 (April), pp. 277-97.

Aunon-Nerin, Daniel, Didier Cossin, Tomas Hricko, Zhijiang Huang, 2002, "Exploring for the Determinants of Credit Risk in Credit Default Swap Transaction Data: Is fixedincome markets information sufficient to evaluate credit risk?", Research Paper Series (HEC-University of Lausanne and FAME).

Avramov, Doron, Tarun Chordia, Gergana Jostova, and Alexander Philipov, 2009, "Credit Ratings and the Cross-Section of Stock Returns," Journal of Financial Markets, Vol. 12, pp. 469-99.

Barr, Richard S., Thomas E. Siems, 1994, "Predicting bank failure using DEA to quantify management quality," Financial Industry Studies Working Paper (Federal Reserve Bank of Dallas).

Benkert, Christoph, 2004, "Explaining Credit Default Swap Premia," Journal of Futures Markets, Vol. 24, pp.71-92.

Bierens, Herman, Jing-zhi Huang, and Weipeng Kong, 2003, “An econometric model of credit spreads with rebalancing, ARCH and jump effects," Working paper (Penn State University).

Blanco, Roberto, Simon Brennan, and Ian W. Marsh, 2005, "An Empirical Analysis of the Dynamic Relation between Investment-Grade Bonds and Credit Default Swaps," Journal of Finance, Vol. LX (October), pp. 2255-81.

Boyd, John H., David E. Runkle, 1993, "Size and Performance of Banking Firms," Journal of Monetary Economics, Vol. 31, pp. 47-67.

Campbell, John T., Glen B. Taksler, 2003, "Equity Volatility and Corporate Bond Yields," Journal of Finance, Vol. 58, pp. 2321-49.

Collin-Dufresne, Pierre, Robert S. Goldstein, and J. Spencer Martin, 2001, “The Determinants of Credit Spread Changes," Journal of Finance, Vol. 56, (December), pp. $2177-207$. 
Consensus Economics 2003-2007, “Consensus Forecasts, Asia pacific Consensus Forecasts, Consensus Forecasts Eastern Europe, Latin American Consensus Forecasts," November and December Issues.

Cremers, Martijn, Joost Driessen, Pascal J. Maenhout, and David Weinbaum, 2004, "Individual Stock-Option Prices and Credit Spreads," Working Paper (Yale ICF).

Driessen, Joost, 2005, “Is Default Event Risk Priced in Corporate Bonds?" Review of Financial Studies, Vol. 18 (January), pp. 165-95.

Duffee, Gregory R., 1998, “The Relation between Treasury Yields and Corporate Bond Yield Spreads," Journal of Finance, Vol. 53 (December), pp. 2225-41.

Ericsson, Jan, Kris Jacobs, and Rodolfo Oviedo, 2009, "The Determinants of Credit Default Swap Premia," Journal of Financial and Quantitative Analysis, Vol. 44 (February), pp. 109-32.

Fabozzi, Frank J., Xiaolin Cheng, and Ren-Raw Chen, 2007, "Exploring the Components of Credit Risk in Credit Default Swaps," Finance Research Letters, Vol. 4, (March), pp.1018.

Huertas, Thomas F., 2009, "Too Big to fail, too Complex to Contemplate: What to do about Systemically Important Firms," Manuscript (Financial Markets Group Conference, London).

International Monetary Fund, 2009, "Guidance to Assess the Systemic Importance of Financial Institutions, Markets and Instruments: Initial Considerations,” Background Paper (A report to the G-20 Finance Ministers and Central Bank Governors).

Kick, Thomas, Michael Koetter, 2007, "Slippery Slopes of Stress: Ordered Failure Events in German Banking," Journal of Financial Stability, Vol. 3, pp.132-48.

King, Thomas B., Daniel A. Nuxoll, and Timothy J. Yeager, 2006, "Are the Causes of Bank Distress Changing? Can Researchers Keep Up?," Federal Reserve Bank of St. Louis Review, Vol. 88 (January/February), pp. 57-80.

Li, Joanne, Yoon S. Shin, William T. Moore, 2005, "Reactions of Japanese Markets to Changes in Credit Ratings by Global and Local Agencies," Journal of Banking and Finance, Vol. 30, pp. 1007-21. 
Marsh, Ian W., Ibrahim Stevens, 2003, "Large Complex Financial Institutions: Common Influences on Asset Price Behavior?," Financial Stability Review, (December), pp. 91101.

Merton, Robert C., 1974, "On the Pricing of Corporate Debt: The Risk Structure of Interest Rates," Journal of Finance, Vol. 29 (Issue 2), pp. 449-70.

Pedrosa, Monica, Richard Roll, 1998, "Systematic Risk in Corporate Bond Credit Spreads," Journal of Fixed Income, Vol. 8 (Issue 3), pp. 7-26.

Poghosyan, Tigran, Martin Cihak, 2009, "Distress in European Banks: An Analysis Based on a New Data Set," Working Paper (IMF).

Rawcliffe, Gerry, Julia Peach, Sharon Haas, James E. Moss, David Marshall, and Peter V. Shaw, 2008, "Bank Rating Methodology," Criteria Report (Fitch Ratings: Banks).

Tang, Dragon Y., Hong Yan, 2010, "Market Conditions, Default Risk and Credit Spreads," Journal of Banking \& Finance, Vol. 34 (April), pp. 743-53.

Thomson, James B., 2009, "On Systematically Important Financial Institutions and Progressive System Mitigation," Policy Discussion Paper No. 27, (Federal Reserve Bank of Cleveland).

Wheelock, David C., Paul W. Wilson, 2000, "Why do Banks Disappear? The Determinants of U.S. Bank Failures and Acquisitions," Review of Economics and Statistics, Vol. 82, (February), pp. 127-3

Windmeijer, Frank, 2005, "A Finite Sample Correction for the Variance of Linear Efficient Two-step GMM Estimators,” Journal of Econometrics, Vol. 126, (May), pp. 25-51. 